\title{
PENGEMBANGAN BAHAN AJAR AKUNTANSI BERBASIS KOMPUTER PADA MATERI BUKU BESAR PADA MATA PELAJARAN AKUNTANSI KELAS X DI SMK YAPIM SIAK HULU
}

(Developing of Computer-Based Accounting Teaching Materials in the Ledger Teaching Materials on Class X Accounting Lessons in Yapim Siak Hulu Vocational School of Academic Year 2016/2017)

Oleh: Akhmad Suyono*)

${ }^{*)}$ Dosen Universitas Islam Riau

ABSTRACT

The objectives of this research are: (1) to find out the process of developing accounting teaching media in the form of interactive CDs with Lectora Inspire Portable ${ }^{\circledR}$ accounting subjects in general ledger material. (2) To find out the feasibility of accounting instructional media in the form of interactive CDs with the Lectora Inspire Portable ${ }^{\circledR}$ accounting software in general ledger material. This type of research is research and development. The development model used is the Borg \& Gall model which starts from the potential and problem stages to strengthen the potential and problems to be studied, the second stage is collecting information by observing school, the third stage is product design that is done in determining $S K \& K D$, indicator, determine teaching materials and will produce a flowchart and storry board, Lectora Inspire Portable ${ }^{\circledR}$, the fourth stage is design validation from Material Experts and Learning Practitioners with $82 \%$ and $96 \%$ revision in Phase I, and Media Experts generate $92 \%$ and $96 \%$ in the revision phase I, and continued with a smallscale trial conducted with 7 students, and continued to a large-scale trial conducted on 15 students who had different abilities, and continued with the making of products for data analysis and obtained the final product of accounting teaching materials in the form of interactive CDs. Based on the results of data analysis and discussion, the results of this study are the availability of valid accounting instructional media through the validity stage and proven feasibility through the trial phase.

Kata Kunci: accounting, computer-based, ledger teaching materials.

\section{PENDAHULUAN}

Di Indonesia pendidikan diartikan dalam Undang-Undang Republik Indonesia Nomor 20 Tahun 2003 "Sebagai usaha sadar terencana untuk mewujudkan suasana belajar dan proses pembelajaran agar peserta didik dapat secara aktif mengembangkan potensi dirinya untuk memiliki kekuatan spiritual keagamaan, pengendalian diri, kepribadian, kecerdasan, akhlak mulia, serta keterampilan yang diperlukan darinya, masyarakat, bangsa, dan Negara".Mudyahardjo, (2012:12) “Tujuan pendidikan merupakan perpaduan tujuantujuan pendidikan yang bersifat pengembangan kemampuan-kemampuan pribadi secara optimal dengan tujuan- tujuan sosial yang bersifat manusia seutuhnya yang dapat memainkan peranannya sebagai warga dalam berbagai lingkungan persekutuan hidup dan kelompok sosial”.

Pendidikan ini sebagai sarana untuk mengembangkan potensi diri, maka berbagai macam usaha untuk meningkatkan mutu didalam pendidikan terus dilakukan, mulai dari pengembangan kurikulum, pemenuhan sarana serta prasarana pendidikan, hingga inovasi dalam pembelajaran. Pengembanganpengembangan ini perlu terus dilakukan karena subjek dan objek dari pendidikan ini adalah manusia yang satu sama lainnya saling berbeda. Karena hal inilah pendidikan harus bersifat dinamis dan 
terus berkembang mengikuti kemajuan peradaban manusia demi memenuhi kebutuhan-kebutuhan manusia yang akan datang dan semakin kompleks.

Pada era globalisasi ini tuntutan pembelajaran yang semakin cepat, efektif, dan efisien tidak dapat dihindari lagi. Untuk mengatasi hal ini diperlukan suatu teknologi yang diterapkan dalam pembelajaran. Sudah selayaknya lembagalembaga pendidikan yang ada segera memperkenalkan dan memulai penggunaan Teknologi Informasi dan Komunikasi (TIK) sebagai basis pembelajaran yang lebih mutakhir.

Hal ini penting, mengingat penggunaan TIK merupakan salah satu faktor penting yang memungkinkan kecepatan transformasi ilmu pengetahuan kepada para peserta didik, generasi bangsa ini secara lebih luas. Darmawan, (2012: 5) "Pendidikan berbasis TIK setidaknya memberikan dua keuntungan. Pertama, sebagai pendorong komunitas pendidikan (termasuk guru) untuk lebih apresiatif proaktif dalam maksimalisasi potensi pendidikan, kedua, memberikan kesempatan luas kepada peserta didik dalam memanfaatkan setiap potensi yang ada, yang dapat di peroleh dari sumbersumber yang tidak terbatas".

Rusman, dkk (2011: 97) "Pembelajaran berbasis komputer merupakan program pembelajaran dengan menggunakan software komputer (CD pembelajaran) berupa program komputer yang berisi tentang muatan pembelajaran meliputi: judul, tujuan, materi pembelajaran, dan evaluasi pembelajaran".

Dengan menciptakan sistem pendidikan seperti ini tentu tidak akan terwujud apabila hanya dilakukan oleh satu orang atau satu kelompok saja, hal yang seperti yang diharapkan ini akan berhasil terwujud apabila segala pihak yang terkait dalam pendidikan ikut ambil bagian dalam mengembangkan pendidikan ini melalui kreatifitasnya masing-masing termasuk guru. Guru sebagai seorang pendidik dituntut untuk memiliki keterampilan- keterampilan dalam mendidik peserta didiknya agar peserta didiknya mau terus mengembangkan seluruh potensi yang dimilikinya dan membentuk karakteristik kepribadiannya kearah yang lebih positif melalui kegiatan pembelajaran dikelas hingga belajar secara mandiri.

Membantu peserta didik melakukan pembelajaran secara mandiri ini diperlukan suatu alat yang bisa digunakan guna membantu peserta didik dalam belajar secara mandiri. Salah satu upaya yang dapat dilakukan untuk mengatasinya adalah dengan menciptakan kesadaran peserta didik untuk mau belajar mandiri, dan salah satu cara untuk mewujudkan hal ini yaitu dengan membuat bahan ajar. Hal ini salah satunya dikarenakan sumber belajar siswa yang berasal dari bahan ajar masih minim.

Rohman dan Amri, (2013: 77) "Bahan ajar atau materi pembelajaran terdiri dari pengetahuan, sikap, dan keterampilan yang dikembangkan berdasarkan Standar Kompetensi Lulusan (SKL), Standar Kompetensi (SK), dan Kompetensi Dasar (KD) pada standar isi yang harus dipelajari oleh siswa dalam rangka mencapai kompetensi yang telah ditentukan". Selanjutnya Rohman dan Amri (2013: 79) "Bahan ajar atau materi mengembangkan ide, memilih, menggunakan bahan, menggunakan peralatan, dan teknik kerja".

Berdasarkan pengamatan pada tanggal 18 januari 2017 Bahan ajar akuntansi yang digunakan para siswa kelas X Akuntansi di SMK YAPIM Siak Hulu hanya Buku double folio, Infokus, LKS dan Buku pelajaran. Padahal, banyak jenis bahan ajar yang dapat digunakan oleh siswa untuk menambah pengetahuan mereka, seperti yang diungkapkan oleh Rohman dan Amri (2013: 84) "sumber bahan ajar/ meteri pembelajaran dapat kita temukan dari berbagai sumber seperti buku pelajaran, majalah, jurnal, koran, internet, media audiovisual, dan sebagainya".

Berdasarkan pengamatan di SMK Yapim Siak Hulu, siswa akan merasa bosan dengan bahan ajar (Buku double 
folio, Infokus, LKS dan Buku pelajaran) yang digunakan selama proses belajar mengajar berlangsung. Pengembangan bahan ajar penting dilakukan oleh pendidik, termasuk pada materi buku besar. Materi buku besar termasuk mata pelajaran yang sangat penting dalam siklus akuntansi, maka dibuat pengembangan bahan ajar agar pembelajaran lebih efektif, efisien dan tidak melenceng dari kompetensi yang akan dicapainya.

Untuk mengatasi permasalahan tersebut maka di perlukan suatu inovasi bahan ajar yang mampu menunjang proses pembelajaran agar pembelajaran menjadi efisien. Dengan melihat kemajuan teknologi zaman sekarang, maka mengembangkan bahan ajar berbasis komputer untuk pembelajaran akuntansi materi buku besar menjadi solusi dalam masalah yang peneliti temukan di SMK YAPIM Siak Hulu. Dengan adanya pengembangan bahan ajar berbasis komputer untuk pembelajaran ini di harapkan peserta didik tidak akan merasa jenuh lagi dalam proses pembelajaran akuntansi. Selain itu di harapkan peserta didik dapat memahami materi yang disampaikan oleh bahan ajar berbasis komputer yang telah di kembangkan. Pengembangan bahan ajar akuntansi berbasis komputer ini dikembangkan agar peserta didik memiliki motivasi untuk dapat belajar secara mandiri.

Adapun bahan ajar akuntansi berbasis komputer yang digunakan yaitu bahan ajar berbasis aplikasi Lectora Inspire Portable $^{\circledR}$, yang mampu membawa peserta didik untuk belajar mandiri dengan motivasi tinggi dan membantu peningkatan hasil belajar peserta didik.

Tujuan penelitian ini yaitu, untuk mengetahui proses pengembangan media bahan ajar akuntansi berupa CD interaktif dengan software Lectora Inspire Portable ${ }^{\circledR}$ mata pelajaran akuntansi pada materi buku besar. dan untuk mengetahui kelayakan media bahan ajar akuntansi berupa CD interaktif dengan software Lectora Inspire Portable $^{\circledR}$ mata pelajaran akuntansi pada materi buku besar pada mata pelajaran akuntansi kelas X di SMK YAPIM Siak Hulu tahun ajaran 2016/2017.

\section{Tinjauan Pustaka \\ Teori Teknologi Pembelajaran}

Hamzah \& Lamatenggo, (2014: 16)

"Teknologi pembelajaran adalah teori dan praktik dalam desain pengembangan, pemanfaatan, pengelolaan serta evaluasi proses dan sumber untuk belajar".

Pendapat lain mengenai pengertian teknologi pembelajaran dikemukakan oleh Mac Kenzie dan Eraut (dalam Warsita, 2008: 15), "Teknologi pembelajaran merupakan suatu studi yang sistematis mengenai cara bagaimana tujuan pendidikan dapat dicapai”.

\section{Hakikat Pembelajaran Berbasis Komputer}

Rusman, dkk, (2011: 97) "Pembelajaran berbasis komputer merupakan program pembelajaran dengan menggunakan software komputer (CD Pembelajaran) berupa program komputer yang berisi tentang muatan pembelajaran meliputi: judul, tujuan, materi pembelajaran, dan evaluasi pembelajaran".

\section{Perangkat Lunak Pembantu Lectora Inspire Portable ${ }^{\circledR}$}

Lectora Inspire adalah perangkat lunak authoring tool untuk pengembangan konten e-learning dan pembelajaran yang dikembangkan oleh Trivantis Corporation (Raharjo, 2013). Lectora Inspire adalah authoring tool untuk pengembangan konten e-learning yang dikembangkan oleh trivantis corporation (mas'ud, 2012: 1). Tahun 2011, lectora memperoleh 5 penghargaan dalam bidang produk $E$ Learning inovatif, Authoring Tool, tool presentasi terbaik, dan teknologi elearning terbaik (Mas'ud, 2012; 1).

Membuat Title multimedia pembelajaran dengan lectora inspire dapat dilakukan dengan 3 cara, yaitu: 
1. Title Wizard, digunakan untuk membuat kerangka Title secara otomatis dengan menentukan style tampilan, jumlah Chapter dan page, test, serta tomboltombol navigasi standar. Biasanya cara Title Wizard bagi pengguna pemula.

2. Template, mirip dengan Title Wizard, akan tetapi hanya sebatas tomboltombol navigasi. Biasanya digunakan oleh pengembang yang sudah agak mahir.

3. Blank Title, cara untuk membuat Title tanpa pilihan style dan bantuan wizard. Biasanya digunakan oleh pengembang yang sudah mahir menggunakan software Lectora (Mas'ud, 2012: 17).

Pembuatan multimedia pembelajaran yang dikembangkan dalam penelitian ini adalah Title Wizard yang terdiri dari pembuatan kerangka Title secara otomatis dengan menentukan style tampilan, jumlah Chapter dan Page, Test, serta tomboltombol navigasi standar.

\section{Pengembangan Bahan Ajar}

Borg \& Gall (1983) (dalam Setyosari Punaiji, 2013: 222) "penelitian pengembangan adalah suatu proses yang dipakai untuk mengembangkan dan memvalididasi produk pendidikan".

Penelitian ini merupakan penelitian pengembangan model Borg \& Gall (dalam Sugiyono, 2014: 298) Prosedur penelitian ini terdiri dari sepuluh langkah, antara lain

1. Potensi dan Masalah

2. Mengumpulkan Informasi

3. Desain Produk

4. Validasi Desain

5. Perbaikan Desain

6. Uji Caba Produk (Skala Kecil)

7. Revisi Produk

8. Uji Coba Pemakaian

9. Revisi Produk

10. Pembuatan Produk (Implementasi)

\section{METODE}

Metode penelitian yang digunakan dalam peneliti adalah penelitian pengembangan (research and development) yang berorientasi pada produk dan bertujuan untuk mengembangkan bahan ajar akuntansi pada mata pelajaran akuntansi pada materi buku besar untuk peserta didik Sekolah Menengah Kejuruan (SMK) YAPIM Siak Hulu kelas $\mathrm{X}$ jurusan Akuntansi. Menurut Borg \& Gall (1983) (dalam Setyosari Punaiji, 2013: 222) "penelitian pengembangan adalah suatu proses yang dipakai untuk mengembangkan dan memvalididasi produk pendidikan".

Hasil akhir dari penelitian ini adalah berupa bahan ajar yang berbentuk CD akuntansi pada materi buku besar, yang dapat digunakan dalam pembelajaran disekolah ataupun secara umum, baik individu maupun kelompok. Subjek penelitian ini adalah Ahli Media yaitu Guru Akuntansi SMK YAPIM Siak Hulu, Ahli Materi yaitu Dosen Pendidikan Ekonomi Akuntansi Universitas Islam Riau, Praktisi Pembelajaran yaitu Guru Akuntansi SMK YAPIM Siak Hulu dan siswa kelas X Kejuruan Akuntansi SMK YAPIM Siak Hulu. Jumlah subjek secara keseluruhan adalah 22 siswa dengan rincian 7 siswa untuk uji coba produk skala kecil dan 15 siswa untuk uji coba pemakaian produk.

Data yang digunakan untuk pengambilan data dalam penelitian ini adalah lembar pengamatan dan observasi. Lembar pengamatan digunakan untuk mengetahui pendapat responden terhadap bahan ajar akuntansi yang dikembangkan. Adapun lembar pengamatan yang digunakan dalam penelitian ini dari Kementerian Pendidikan Nasional (2010: 18-21) dan Kementerian Pendidikan Nasional (2008: 29). Observasi digunakan untuk melihat kebutuhan yang diperlukan dilapangan.

Data yang telah terkumpul akan dianalisis untuk mengetahui penilaian dan pendapat dari produk yang dihasilkan.

1. Data proses pengembangan produk

Data proses pengembangan produk merupakan data deskriptif. Data proses pengembangan produk 
diperoleh dari Ahli Materi, Ahli Media, Praktisi Pembelajaran dan Siswa.

2. Data penilaian kelayakan produk

Data penilaian produk diperoleh dari isian angket oleh Ahli Media, Ahli Materi, dan Praktisi Pembelajaran dan Siswa. Data selanjutnya dianalisis dengan mengikuti langkah-langkah sebagai berikut:

a. Skala persentase yang digunakan untuk mengetahui kelayakan produk

\section{Tabel Kriteria Intepretasi}

\begin{tabular}{ll}
\hline Kriteria & Interprestasi \\
\hline $0,80-1,00$ & Tinggi \\
\hline $0,60-0,80$ & Cukup \\
\hline $0,40-0,60$ & Agak Rendah \\
\hline $0,20-0,40$ & Rendah \\
\hline $0,00-0,20$ & Sangat Rendah \\
\hline
\end{tabular}

(Sumber: Suharsimi Arikunto, 2013: 89)

b. Menghitung nilai rata-rata skor tiap indikator dengan rumus:

$$
\begin{aligned}
& \text { Persentase Kelayakan } \\
& \qquad=\frac{\text { Skor yang diperoleh }}{\text { Skor maksimal }} \\
& \times 100 \%
\end{aligned}
$$$$
\text { Sugiyono (2009: 419) }
$$

Setelah penyajian dalam bentuk nilai, langkah selanjutnya mendeskripsikan dan mengambil kesimpulan tentang masingmasing indikator.

Produk dinyatakan layak apabila telah melalui tahap validasi dengan persentase kelayakan minimal $75 \%$.

\section{HASIL PENELITIAN DAN PEMBAHASAN}

Prosedur Pengembangan Media Bahan Ajar Akuntansi

1. Potensi dan Masalah

Berdasarkan pengamatan pada tanggal 18 januari 2017 Bahan ajar akuntansi yang digunakan para siswa kelas X Akuntansi di SMK YAPIM
Siak Hulu hanya Buku double folio, Infokus, LKS dan Buku pelajaran. Padahal, banyak jenis bahan ajar yang dapat digunakan oleh siswa untuk menambah pengetahuan mereka, seperti yang diungkapkan oleh Rohman dan Amri (2013: 84) "sumber bahan ajar/ materi pembelajaran dapat kita temukan dari berbagai sumber seperti buku pelajaran, majalah, jurnal, koran, internet, media audiovisual, dan sebagainya".

2. Mengumpulkan Informasi

Pengumpulan informasi dalam penelitian pengembangan bahan ajar akuntansi ini, dengan melakukan observasi ke sekolah pada tanggal 18 januari 2017 dengan melihat bahan ajar apa saja digunakan di dalam sekolah. Tujuan dari pengumpulan informasi bahan ajar akuntansi materi buku besar adalah untuk menemukan solusi dalam masalah. Dengan adanya pengembangan bahan ajar berbasis komputer untuk pembelajaran ini, diharapkan peserta didik tidak akan merasa jenuh lagi dalam proses pembelajaran akuntansi.

3. Desain Produk

1) Menentukan standar kompetensi, kompetensi dasar, dan indikator

2) Menentukan materi ajar

3) Membuat contoh soal dan soalsoal Latihan

4) Menyusunan flowchart bahan ajar akuntansi

5) Menyusunan storry board bahan ajar akuntansi

6) Mengedit gambar

7) Mengedit video

8) Membuat desain tampilan

9) Menyusun bahan ajar akuntansi menggunakan software lectora inspire portable ${ }^{\circledR}$

10) Instalasi bahan ajar akuntansi ke Compact Disk (CD)

4. Validasi Desain

a. Uji Coba Pertama (Uji Coba Ahli)

1) Uji Coba Ahli Materi (Dosen Pendidikan Akuntansi) 
Hasil penilaian oleh Ahli Materi dari Dosen Pendidikan akuntansi Univesitas Islam Riau yang ditinjau dari aspek substansi materi dan desain pembelajaran. Penilaian ahli materi dari dosen pendidikan akuntansi terhadap media bahan ajar akuntansi dengan menggunakan Software lectora inspire portable ${ }^{\circledR}$ sebesar $82 \%$ yang diintresperstasikan tinggi. Setelah melakukan revisi tahap I terhadap Media bahan ajar akuntansi mendapat $88 \%$, artinya media bahan ajar mengalami kenaikan $6 \%$ seperti yang tergambar pada grafik I.

2) Uji Coba Praktisi Pembelajaran (Guru Akuntansi SMK YAPIM Siak Hulu)

Hasil penilaian oleh Praktisi Pembelajaran dari Guru Akuntansi SMK Yapim Siak Hulu yang ditinjau dari aspek substansi materi dan desain pembelajaran. Penilaian praktisi pembelajaran dari guru akuntansi terhadap media bahan ajar akuntansi dengan menggunakan Software lectora inspire portable ${ }^{\circledR}$ sebesar $82 \%$ yang diintresperstasikan tinggi. Setelah melakukan revisi tahap I terhadap Media bahan ajar akuntansi mendapat $88 \%$, artinya media bahan ajar mengalami kenaikan $6 \%$ Seperti yang tergambar pada grafik I.

3) Uji Coba Ahli Media

Hasil penilaian oleh Ahli Media dari Guru Akuntansi SMK YAPIM Siak Hulu yang ditinjau dari tampilan komunikasi visual, dan pemanfaatan software. Penilaian ahli materi dari guru akuntansi terhadap media bahan ajar akuntansi dengan menggunakan Software lectora inspire portable ${ }^{\circledR}$ sebesar $\quad 92 \% \quad$ yang diintresperstasikan tinggi. Setelah melakukan revisi tahap II terhadap Media bahan ajar akuntansi mendapat $96 \%$, artinya media bahan ajar mengalami kenaikan $4 \%$ seperti yang tergambar pada grafik 1.1.

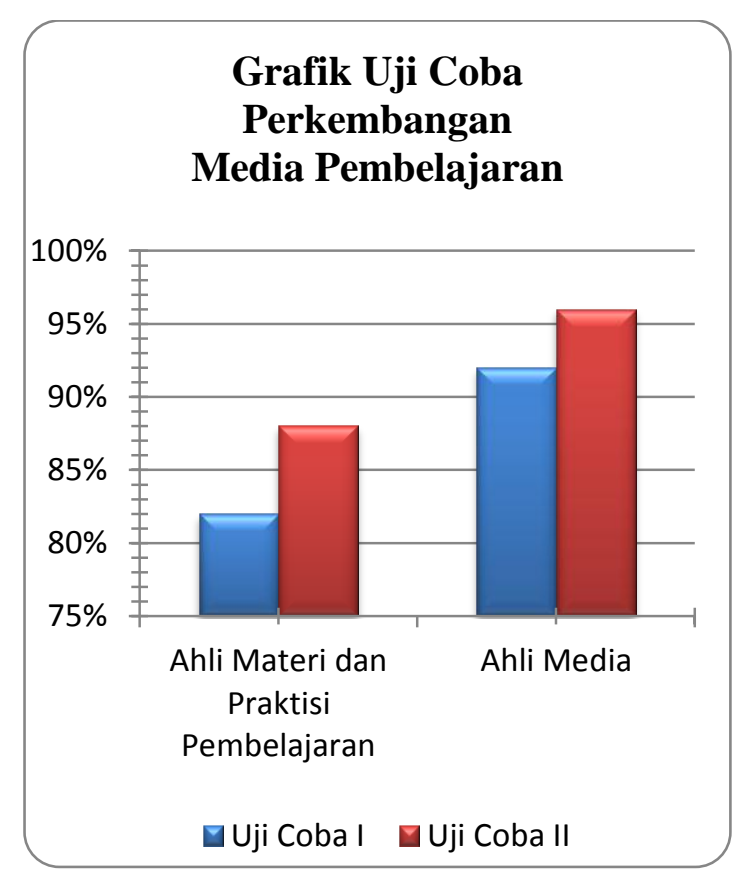

b. Uji Coba Produk (Skala Kecil)

Hasil penilaian oleh uji coba produk (skala kecil) yang terdiri dari 7 siswa kelas X Akuntansi di SMK YAPIM Siak Hulu yang ditinjau dari kelayakan isi, kebahasaan, sajian, dan tampilan. Penilaian uji coba produk (skala kecil) terhadap media bahan ajar akuntansi menggunakan software lectora inspire portable ${ }^{\circledR}$ sebesar $83 \%$ yang di intresprestasikan tinggi, sehingga layak digunakan sebagai media bahan ajar akuntansi seperti grafik 


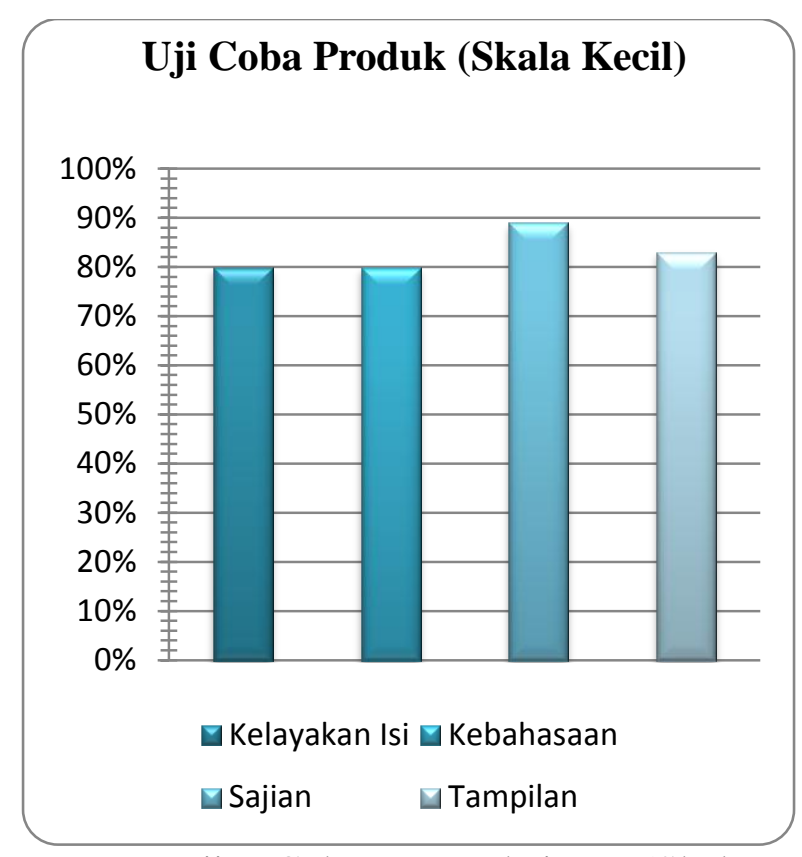

c. Uji Coba Pemakaian (Skala Besar)

Hasil penilaian oleh uji coba pemakaian (skala besar) yang terdiri dari 15 siswa kelas $X$ Akuntansi di SMK YAPIM Siak Hulu yang ditinjau dari kelayakan isi, kebahasaan, sajian, dan tampilan. Penilaian uji coba produk (skala kecil) terhadap media bahan ajar akuntansi menggunakan software lectora inspire portable ${ }^{\circledR}$ sebesar $90 \%$ yang di intresprestasikan tinggi, sehingga layak digunakan sebagai media bahan ajar akuntansi seperti grafik.

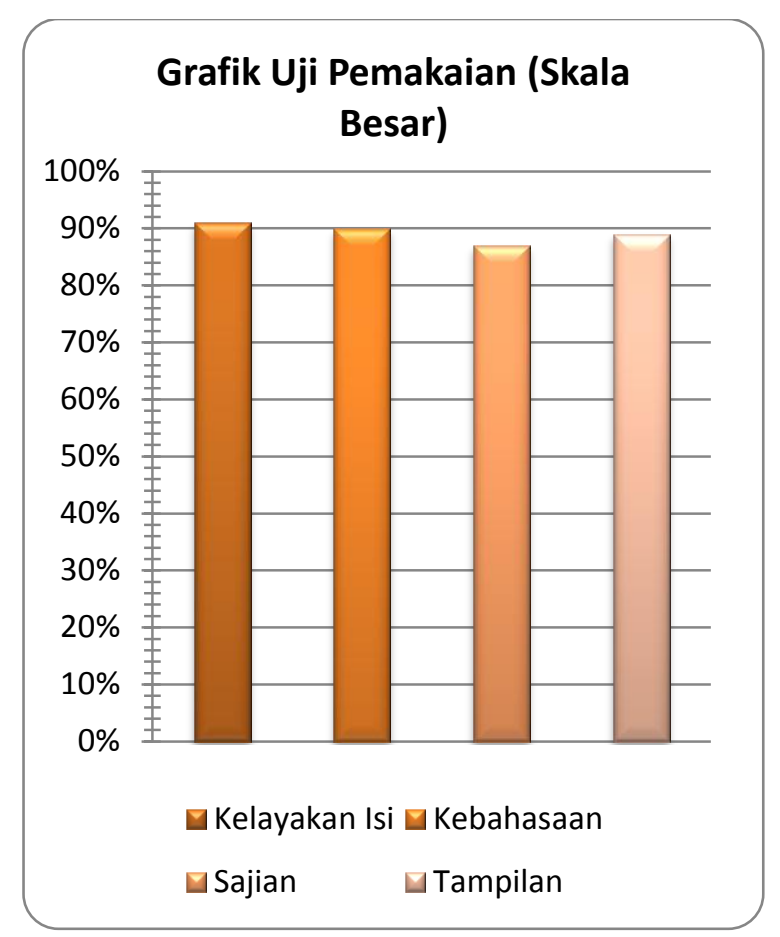

\section{KESIMPULAN}

1. Pengembangan media bahan ajar akuntansi untuk siswa kelas $\mathrm{X}$ Akuntansi dibuat dengan software lectora portable ${ }^{\circledR}$ pada materi buku besar pada mata pelajaran akuntansi melalui beberapa tahapan seperti: a) Potensi masalah, b) Mengumpulkan informasi, c) Desain produk, d) Validasi produk, e) Perbaikan Desain, f) Uji coba produk (skala kecil), g) Revisi produk, h) Uji coba pemakaian, i) pembuatan produk (implementasi).

2. Hasil pengujian kelayakan media bahan ajar akuntansi mengungkapkan bahwa media bahan ajar akuntansi telah layak digunakan dalam proses pembelajaran menurut pendapat ahli materi, praktisi pembelajaran, ahli media dan siswa.

\section{Saran}

Berdasarkan kesimpulan dan dengan memperhatikan keterbatasan penelitian, maka saran yang dapat diajukan adalah sebagai berikut:

1. Bagi Peneliti Selanjutnya

Dapat menjadi acuan bagi peneliti dalam mengembangkan pada materi lain.

2. Bagi Guru 
Dapat digunakan sebagai masukan oleh guru dalam mengembangkan bahan ajar bagi siswa.

3. Bagi peserta didik

a. Dapat menggunakan media pembelajaran untuk meningkatkan gairah belajar secara mandiri.

b. Dapat menggunakan media pembelajaran untuk meningkatkan motivasi dalam melakukan aktivitas belajar dalam pembelajaran dengan menggunakan bahan ajar yang kreatif dan menyenangkan.

\section{DAFTAR PUSTAKA}

Arikunto, Suharsimi. (2013). Dasar-dasar Evaluasi Pendidikan (edisi ke 2). Jakarta: Bumi Aksara.

Hamzah B. uno dan Nina Lamatenggo. (2014). Teknologi dan Komunikasi \& Informasi Pembelajaran. Jakarta: Bumi Aksara.

Darmawan, Deni. (2012). Teknologi Pembelajaran. Bandung: PT. Remaja Rosdakarya.

Kemdiknas. (2008). Sosialisasi KTSP: Pengembangan Bahan Ajar. Jakarta: Kemeterian Pendidikan Nasional.

Mas'ud, Muhammad. (2012). Membuat Multimedia Pembelajaran Dengan
Lectora Inspire. Yogyakarta: Pustaka Shonif.

Mudyahardjo, Redja. (2012). Pengantar Pendidikan. Jakarta: Rajawali Pers.

Rahardjo, (2013). Lectora Portable. http://rahardjo.guru-indonesia.net. (diakses pada tanggal 23 Mei 2017)

Rohman, Muhammad dan Amri, Sofan. (2013). Strategi \& Desain Pengembangan Sistem Pembelajaran. Jakarta: Prestasi Pustaka.

Rusman, dkk. (2011). Pembelajaran Berbasis Teknologi Informasi dan Komunikaso. Jakarta: Rajawali Pers.

Setyosari, Punaji. (2013). Metode Penelitian Pendidikan Dan Pengembangan (edisi ke 3). Jakarta: Kencana.

Sugiyono. (2009). Metode Penelitian Bisnis (Pendekatan Kuantitatif, Kualitatif, dan $R \& D)$. Bandung: Alfabeta.

- (2013). Metode Penelitian Administrasi. Bandung: Alfabeta

- (2014). Metode Penelitian Kuantitatif, Kualitatif Dan $R \& D$. Bandung: Alfabeta

UU No. 20 Tahun 2003.Tentang Sistem Pendidikan Nasional.

Warsita, Bambang. (2008). Teknologi Pembelajaran, Landasan Dan Aplikasinya. Jakarta: Rineka Cipta 
